\title{
Changes in ovarian cancer survival during the 20 years before the era of targeted therapy
}

\author{
Jung-Yun Lee ${ }^{1}$, Sunghoon Kim¹, Young Tae Kim¹, Myong Cheol Lim², Boram Lee ${ }^{3}$, Kyu-Won Jung 3 , \\ Jae Weon Kim ${ }^{4}$, Sang-Yoon Park ${ }^{2}$ and Young-Joo Won ${ }^{3^{*}}$
}

\begin{abstract}
Background: The survival of patients with ovarian cancer has improved because of surgery and chemotherapy. This study aimed to estimate the changes in survival rates among Korean women with ovarian cancer prior to the introduction of targeted therapy for ovarian cancer.

Methods: Data were obtained from the Korea Central Cancer Registry regarding patients who were diagnosed with epithelial ovarian cancer between 1995 and 2014. The relative survival rates were calculated for 5-year periods using the Ederer II method. Cox proportional hazard models were created to assess the associations of demographic and clinicopathological factors with ovarian cancer survival.

Results: During the study period, 22,880 women were diagnosed with epithelial ovarian cancer. The 5-year relative survival rate improved from $57.2 \%$ during $1995-1999$ to $63.8 \%$ during $2010-2014(P<0.001)$. Survival outcomes improved between 1995 and 1999 and 2010-2014 for the serous and endometrioid carcinoma subtypes $(P<0.001)$. However, no improvements were observed for the mucinous and clear cell carcinoma subtypes $(P=0.189$ and $P=0.293$, respectively). Multivariate analysis revealed that younger age, early stage, recent diagnosis, primary surgical treatment, and non-serous histological subtype were favorable prognostic factors.

Conclusion: Survival outcomes have improved for serous and endometrioid epithelial ovarian cancer in the last 20 years. However, no improvement was observed for patients with mucinous and clear cell carcinoma subtypes.
\end{abstract}

Keywords: Ovarian cancer, Survival, Histology, Korea, Chemotherapy, Surgery

\section{Background}

Ovarian cancer is the most common cause of gynecological cancer-related death in Korea, and causes approximately 1021 deaths annually [1]. The incidence and mortality of ovarian cancer have increased continuously, and 2413 new cases were detected in 2014 [1-3]. Approximately $75 \%$ of the newly diagnosed patients have advanced-stage disease, which partly explains the high mortality rate for this cancer $[4,5]$.

During the last 20 years, there has been an improvement in survival of patients with ovarian cancer $[1,4-6]$. A number of strategies have been evaluated with the

\footnotetext{
* Correspondence: astra67@ncc.re.kr

${ }^{3}$ Cancer Registration and Statistics Branch, National Cancer Center, Goyang,

South Korea

Full list of author information is available at the end of the article
}

goal of improving survival, and some of these strategies have become standard treatments for ovarian cancer. For example, debulking surgery has been emphasized because optimal cytoreduction is one of the most significant predictors of survival [7], and previous studies have revealed that optimal surgical cytoreduction improves survival in cases of advanced-stage disease [8]. In addition, paclitaxel plus cisplatin has been introduced as a front-line therapy for ovarian cancer, and provides better survival outcomes than cyclophosphamide-based regimens [9]. After then, platinum-based chemotherapy has been improved with less toxic and equivalent analogs, carboplatin $[10,11]$, and paclitaxel plus carboplatin is the most commonly used first-line therapy for ovarian cancer. Moreover, better survival rates have been observed in patients with recurrent disease, with a number of chemotherapies having

(c) The Author(s). 2018 Open Access This article is distributed under the terms of the Creative Commons Attribution 4.0 International License (http://creativecommons.org/licenses/by/4.0/), which permits unrestricted use, distribution, and reproduction in any medium, provided you give appropriate credit to the original author(s) and the source, provide a link to the Creative Commons license, and indicate if changes were made. The Creative Commons Public Domain Dedication waiver (http://creativecommons.org/publicdomain/zero/1.0/) applies to the data made available in this article, unless otherwise stated. 
activity even in platinum-resistant settings. Although recent phase III trials have supported the introduction of targeted agents [12-14], their economic cost, limited insurance coverage, and low patient preference have limited the use of these agents in routine clinical practice $[15,16]$. In Korea, the addition of bevacizumab to standard chemotherapy was approved in 2013, and the national insurer only began covering the cost of bevacizumab for platinum-resistant recurrent ovarian cancer in August 2015. Therefore, the present study aimed to investigate the changes in the survival rates among Korean patients with ovarian cancer during the last 20 years, and to identify unmet clinical needs that might be targeted to improve outcomes.

\section{Methods}

This study utilized data from the Korean National Cancer Incidence Database (KNCIDB), which includes data from the Korea Central Cancer Registry (KCCR) and information regarding patients' demographic characteristics, primary cancer site, morphology, diagnosis date, and initial treatment. KCCR was launched as a nationwide hospital-based cancer registry in 1980 by the Ministry of Health and Welfare, and subsequently expanded to cover the entire population in 1999. The present study evaluated survival data from the KNCIDB. The ovary cancer cases were classified according to the International Classification of Diseases for Oncology, 3rd edition [17] and converted according to the International Statistical Classification of Diseases and Related Health Problems, 10th edition (ICD-10: C-56) [18]. We included only cases of epithelial ovarian cancer, diagnosed between 1995 and 2014. All cases of non-epithelial ovarian cancer (e.g. sex-cord stromal tumors and germ cell tumors) were excluded. All cases followed until 31 December 2015.

The present study's retrospective design was approved by the institutional review board of the National Cancer Center (NCC2017-0168).

Age at the diagnosis was classified as $<40$ years old, 40-59 years old, and $>59$ years old. Histological subtypes were categorized as serous carcinoma, mucinous carcinoma, endometrioid carcinoma, clear cell carcinoma, and others. Staging information was based on the Surveillance, Epidemiology, and End Results (SEER) summary staging [19], which categorizes cancer spread from its origin (localized, regional, and distant), because the KCCR has collected this information since 2005. Primary treatments within 4 months were categorized as surgery, chemotherapy, and others.

For the survival analyses, we obtained the data from KNCIDB and the mortality data from Statistics Korea. Relative survival is the ratio of the observed survival rate among patients with cancer, compared to the expected survival rate among age- and sex-matched individuals from the general population. We calculated the relative survival rates (RSRs) using the Ederer II method [20]. Furthermore, we divided the patients into 5-year cohorts based on their diagnosis date to evaluate their 5-year RSRs (1995-1999, 2000-2004, 2005-2009, and 20102014). The Cox regression proportional hazard model adjusted to estimate hazard ratio (HR) for the age at diagnosis, SEER stage, year of diagnosis, primary treatment (with or without surgery), and histological subtype [21]. The proportionality of hazards assumption over time was tested for each factor [22]. All analyses were performed using SAS software (version 9.3; SAS Institute, Cary, NC, USA).

\section{Results}

A total of 22,880 women were diagnosed with ovarian cancer between 1995 and 2014, and their characteristics are shown in Table 1. The overall 5-year RSR significantly improved during study period (57.2\% during 1995-1999, 60.2\% during 2000-2004, 59.4\% during 2005-2009, 63.8\% during 2010-2014; P for trend < 0.001) (Fig. 1). Figure 2 shows the survival outcomes according to histological subtype, which improved for the serous and endometrioid carcinoma subtypes between 1995 and 1999 and 2010-2014 (P for trend $<0.001$ ). However, no significant improvements were observed for the mucinous and clear cell carcinoma subtypes ( $\mathrm{P}$ for trend $=0.189$ and 0.293 , respectively).

Table 2 shows the 5 -year RSRs of patients with ovarian cancer according to histological subtype and SEER stage. The overall 5-year RSRs improved from 59.4\% during 2005-2009 to $63.8 \%$ during 2010-2014 $\quad(P<0.001)$. Improved survivals were also observed for early-stage serous carcinoma (from $77.7 \%$ during 2005-2009 to $84.1 \%$ during 2010-2014). Furthermore, there was a significant increase in the 5-year RSR for advanced-stage serous carcinoma, from $44.1 \%$ during $2005-2009$ to $49.5 \%$ during 2010-2014. However, women with non-serous carcinoma subtypes did not experience a survival improvement, with the exception of women with early-stage endometrioid carcinoma.

Table 3 shows the results for the age-based changes in the 5-year RSRs. During 2005-2009 and 2010-2014, patients who were 40-59 years old and $>59$ years old experienced an increased 5-year survival rate, although younger patients did not experience a survival improvement, regardless of their cancer stage. Patients who underwent surgery had a significantly higher 5-year RSR, compared to patients who did not undergo surgery, and this association strengthened over time.

In the Cox multivariate model, the significant prognostic factors were age at diagnosis, SEER stage, primary treatment, and histological subtype. Furthermore, year of diagnosis was an independent prognostic factor, with patients who were diagnosed during 2010-2014 being 27\% 
Table 1 Basic characteristics according to the time period of ovarian cancer diagnosis

\begin{tabular}{|c|c|c|c|c|c|c|c|c|c|c|c|c|}
\hline & \multicolumn{3}{|l|}{ Total } & \multirow{2}{*}{\multicolumn{2}{|c|}{$\frac{1995-1999}{(n=3740)}$}} & \multirow{2}{*}{\multicolumn{2}{|c|}{$\frac{2000-2004}{(n=4863)}$}} & \multirow{2}{*}{\multicolumn{2}{|c|}{$\frac{2005-2009}{(n=6317)}$}} & \multirow{2}{*}{\multicolumn{2}{|c|}{$\frac{2010-2014}{(n=7960)}$}} & \multirow[b]{3}{*}{$p$-value } \\
\hline & \multicolumn{3}{|l|}{$(n=22,880)$} & & & & & & & & & \\
\hline & No. of cases & $\%$ & $p$-value & No. of cases & $\%$ & No. of cases & $\%$ & No. of cases & $\%$ & No. of cases & $\%$ & \\
\hline Age (years) & & & $<.0001$ & & & & & & & & & $<.0001$ \\
\hline$<40$ & 3849 & 16.8 & & 945 & 25.3 & 910 & 18.7 & 990 & 15.7 & 1004 & 12.6 & \\
\hline $40-59$ & 12,169 & 53.2 & & 1813 & 48.5 & 2526 & 51.9 & 3378 & 53.5 & 4452 & 55.9 & \\
\hline$>59$ & 6862 & 30.0 & & 982 & 26.3 & 1427 & 29.3 & 1949 & 30.9 & 2504 & 31.5 & \\
\hline SEER Stage & & & $<.0001$ & & & & & & & & & $<.0001$ \\
\hline Localized & 3865 & 16.9 & & - & - & - & - & 1683 & 26.6 & 2182 & 27.4 & \\
\hline Regional & 2564 & 11.2 & & - & - & - & - & 1053 & 16.7 & 1511 & 19.0 & \\
\hline Distant & 6795 & 29.7 & & - & - & - & - & 2843 & 45.0 & 3952 & 49.6 & \\
\hline Unspecified & 9656 & 42.2 & & - & - & - & - & 738 & 11.7 & 315 & 4.0 & \\
\hline Primary treatment & & & $<.0001$ & & & & & & & & & $<.0001$ \\
\hline Surgery only & 6007 & 26.3 & & 1213 & 32.4 & 1252 & 25.7 & 1626 & 25.7 & 1916 & 24.1 & \\
\hline Chemotherapy only & 1680 & 7.3 & & 326 & 8.7 & 371 & 7.6 & 414 & 6.6 & 569 & 7.1 & \\
\hline Surgery + Chemotherapy & 13,262 & 58.0 & & 1745 & 46.7 & 2713 & 55.8 & 3805 & 60.2 & 4999 & 62.8 & \\
\hline Others & 1931 & 8.4 & & 456 & 12.2 & 527 & 10.8 & 472 & 7.5 & 476 & 6.0 & \\
\hline Histology & & & $<.0001$ & & & & & & & & & $<.0001$ \\
\hline Serous carcinoma & 10,837 & 47.4 & & 1459 & 39.0 & 2119 & 43.6 & 3186 & 50.4 & 4073 & 51.2 & \\
\hline Mucinous carcinoma & 4005 & 17.5 & & 916 & 24.5 & 1027 & 21.1 & 951 & 15.1 & 1111 & 14.0 & \\
\hline Endometrioid carcinoma & 2191 & 9.6 & & 399 & 10.7 & 494 & 10.2 & 580 & 9.2 & 718 & 9.0 & \\
\hline Clear cell carcinoma & 1923 & 8.4 & & 164 & 4.4 & 327 & 6.7 & 551 & 8.7 & 881 & 11.1 & \\
\hline Others & 3924 & 17.2 & & 802 & 21.4 & 896 & 18.4 & 1049 & 16.6 & 1177 & 14.8 & \\
\hline
\end{tabular}

SEER Surveillance, Epidemiology, and End Results

less likely to die, compared to patients who were diagnosed during 1995-1999 (hazard ratio: 0.73; 95\% confidence interval: 0.65-0.81) (Table 4).

\section{Discussion}

Between 1995 and 2014, there has been a gradual increase in the survival of Korean patients with ovarian

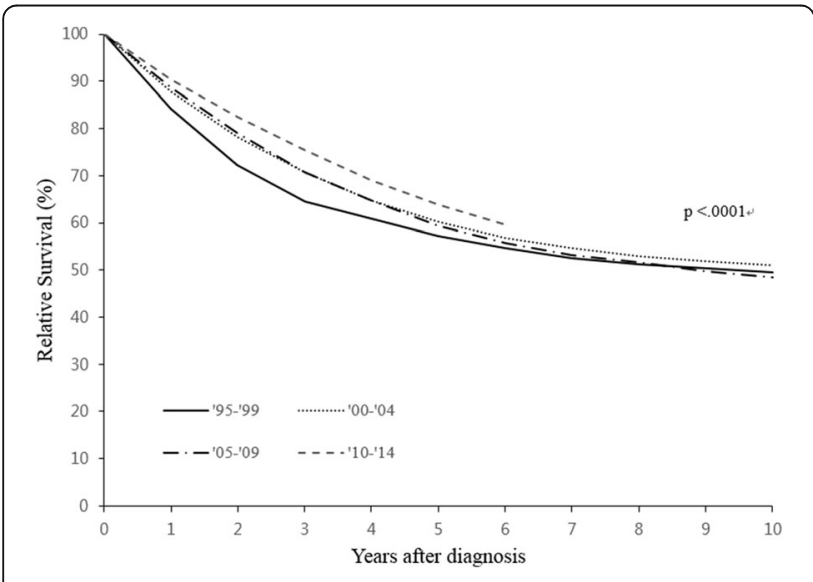

Fig. 1 Relative survival rate of ovary cancer by time period cancer. Among women with serous carcinoma, the risk of death from ovarian cancer during 2010-2014 was $4.7 \%$ lower, compared to during 2005-2009, and 8.5\% lower compared to during 1995-1999. Improvement of survival was found for both early stage and distant stage. However, no improvements were observed for patients with the mucinous and clear cell carcinoma subtypes.

The current approach to managing ovarian cancer involves cytoreductive surgery followed by chemotherapy, and a decrease in the proportion of patients without definitive treatment has been observed during the last 20 years (from $12.2 \%$ during $1995-1999$ to $6.0 \%$ during 2010-2014). Thus, an increasing number of Korean patients have benefited from surgery and chemotherapy, and adherence to the standard treatment guidelines is an independent predictor of improved survival [23, 24]. Furthermore, in the present study, the multivariate analysis revealed that surgery was independently associated with better outcomes.

The use of platinum-based chemotherapy has improved with the development of less toxic analogs (carboplatin), as well as research regarding the optimal dose, schedule, sequence, and duration of treatment. In this 


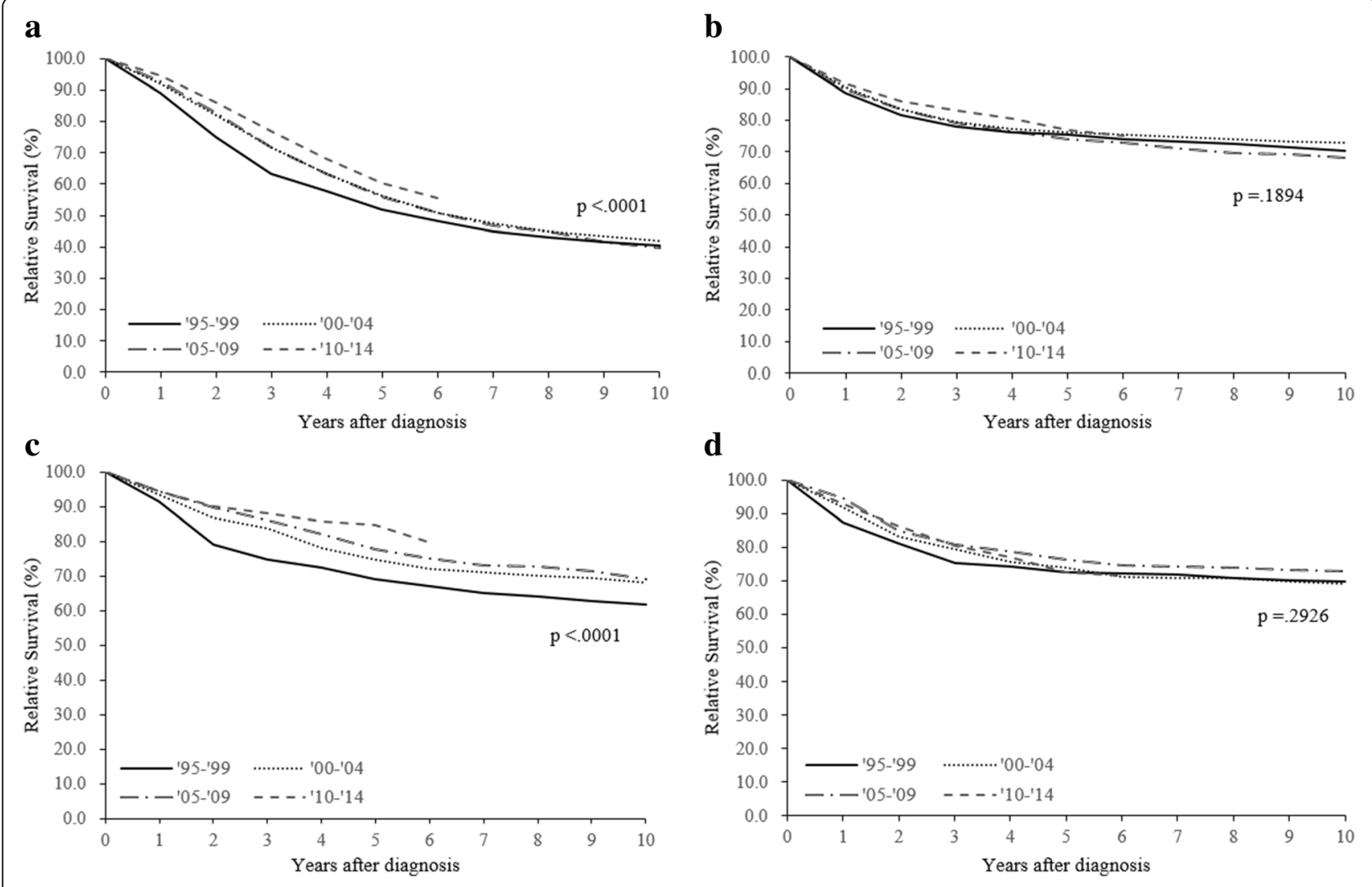

Fig. 2 Trends in relative survival rate according to histology and the time period (a) serous carcinoma (b) mucinous carcinoma (c) endometrioid carcinoma (d) clear cell carcinoma

context, the Gynecologic Oncology Group (GOG) 0111 and OV10 studies revealed that cisplatin plus paclitaxel was superior to cisplatin plus cyclophosphamide $[9,25]$. In addition, the GOG 0158 and Arbeitsgemeinschaft Gynäkologische Onkologie Ovarian Cancer Study Group (AGO-OVAR) studies demonstrated that carboplatin

Table 2 Five-year relative survival rate, by SEER stage and histologic subtype

\begin{tabular}{lllr}
\hline & $\begin{array}{l}2005-2009 \\
(n=6317)\end{array}$ & $\begin{array}{l}2010-2014 \\
(n=7960)\end{array}$ & $p$-value \\
\hline Early stage $^{\text {a }}$ & 81.5 & 86.3 & $<.0001$ \\
Serous carcinoma & 77.7 & 84.1 & $<.0001$ \\
Mucinous carcinoma & 87.6 & 88.6 & 0.379 \\
Endometrioid carcinoma & 88.5 & 93.6 & 0.047 \\
Clear cell carcinoma & 86.4 & 87.4 & 0.673 \\
Distant stage & 38.7 & 43.9 & $<.0001$ \\
Serous carcinoma & 44.1 & 49.5 & $<.0001$ \\
Mucinous carcinoma & 30.2 & 31.5 & 0.247 \\
Endometrioid carcinoma & 50.3 & 60.1 & 0.752 \\
Clear cell carcinoma & 38.0 & 22.5 & 0.012 \\
\hline
\end{tabular}

SEER Surveillance, Epidemiology, and End Results ${ }^{a}$ Early stage: local + regional
Table 3 Five-year relative survival rate, by age and primary treatment

\begin{tabular}{|c|c|c|c|}
\hline & $\begin{array}{l}2005-2009 \\
(n=6317) \\
\end{array}$ & $\begin{array}{l}2010-2014 \\
(n=7960) \\
\end{array}$ & $p$-value \\
\hline \multicolumn{4}{|l|}{ Age } \\
\hline Early stage $^{\mathrm{a}}$ & 81.5 & 86.3 & $<.0001$ \\
\hline$<40$ & 89.1 & 91.6 & 0.203 \\
\hline $40-59$ & 83.9 & 88.1 & $<.0001$ \\
\hline$>59$ & 66.8 & 77.0 & 0.001 \\
\hline Distant stage & 38.7 & 43.9 & $<.0001$ \\
\hline$<40$ & 46.2 & 44.7 & 0.808 \\
\hline $40-59$ & 44.9 & 50.5 & $<.0001$ \\
\hline$>59$ & 28.2 & 34.1 & 0.002 \\
\hline \multicolumn{4}{|l|}{ Surgery } \\
\hline Early stage $^{a}$ & 81.5 & 86.3 & $<.0001$ \\
\hline with surgery & 82.6 & 87.1 & $<.0001$ \\
\hline without surgery & 62.3 & 60.7 & 0.383 \\
\hline Distant stage & 38.7 & 43.9 & $<.0001$ \\
\hline with surgery & 42.5 & 47.6 & $<.0001$ \\
\hline without surgery & 24.0 & 27.2 & 0.413 \\
\hline
\end{tabular}

aEarly stage: local + regional 
Table 4 Estimated hazard ratio of ovarian cancer prior to the era of targeted therapy

\begin{tabular}{|c|c|c|c|c|c|}
\hline & $N$ & No. of deaths & Adjusted $\mathrm{HR}^{\mathrm{b}}$ & $95 \% \mathrm{Cl}$ & $p$-value \\
\hline \multicolumn{6}{|l|}{ Age (years) } \\
\hline$<40$ & 3849 & 988 & ref. & ref. & - \\
\hline $40-59$ & 12,169 & 4992 & 1.71 & $(1.60-1.84)$ & $<.0001$ \\
\hline$>59$ & 6862 & 4328 & 3.00 & $(2.79-3.22)$ & $<.0001$ \\
\hline \multicolumn{6}{|l|}{ SEER Stage } \\
\hline Early stage $e^{a}$ & 6429 & 1113 & ref. & ref. & - \\
\hline Distant stage & 6795 & 3777 & 3.23 & $(3.02-3.46)$ & $<.0001$ \\
\hline \multicolumn{6}{|l|}{ Year of diagnosis } \\
\hline 1995-1999 & 3740 & 2230 & ref. & ref. & - \\
\hline $2000-2004$ & 4863 & 2671 & 0.89 & $(0.84-0.95)$ & 0.000 \\
\hline 2005-2009 & 6317 & 3227 & 0.94 & $(0.85-1.03)$ & 0.185 \\
\hline 2010-2014 & 7960 & 2180 & 0.73 & $(0.65-0.81)$ & $<.0001$ \\
\hline \multicolumn{6}{|l|}{ Primary treatment } \\
\hline With surgery & 19,776 & 8122 & ref. & ref. & - \\
\hline Without surgery & 1772 & 1233 & 1.49 & $(1.39-1.58)$ & $<.0001$ \\
\hline \multicolumn{6}{|l|}{ Histology } \\
\hline Serous carcinoma & 10,837 & 5325 & ref. & ref. & - \\
\hline Mucinous carcinoma & 4005 & 1226 & 0.71 & $(0.67-0.76)$ & $<.0001$ \\
\hline Endometrioid carcinoma & 2191 & 670 & 0.69 & $(0.63-0.75)$ & $<.0001$ \\
\hline Clear cell carcinoma & 1923 & 507 & 0.80 & $(0.73-0.88)$ & $<.0001$ \\
\hline Others & 3924 & 2580 & 1.49 & $(1.42-1.57)$ & $<.0001$ \\
\hline
\end{tabular}

${ }^{a}$ Early stage: local + regional, $\mathrm{HR}$, hazard ratio; ref., reference; $\mathrm{Cl}$, confidence interval; SEER, Surveillance, Epidemiology, and End Results

badjusted for Age, SEER stage, Year of Diagnosis, Primary treatment and Histology

plus paclitaxel was not inferior to cisplatin plus paclitaxel $[10,11]$. Thus, the incorporation of paclitaxel into first-line therapy has improved the ovarian cancer survival rate. This change was adopted by Korean gynecologic oncologists during 2000-2004, and may partially explain the improvement in survival between 1995 and 1999 and 2010-2014.

However, after the incorporation of paclitaxel into first-line chemotherapy, the first-line chemotherapy options have not substantially changed during the last decade. Although a randomized phase III trial revealed a survival benefit after treatment using intraperitoneal chemotherapy [26], this procedure has not been widely accepted in Korea. The Japanese Gynecologic Oncology Group (JGOG) 3016 study also revealed the superiority of dose-dense weekly paclitaxel plus carboplatin, compared to the standard dosing of paclitaxel [27], although this approach also has limited acceptance in Korea.

Previous studies have emphasized the importance of debulking surgery for ovarian cancer. Bristow et al. found that maximal cytoreduction was one of the most powerful determinants of survival among patients with advanced disease during the platinum era [8]. Thus, many Korean gynecologic oncologists adopted radical surgery and a multidisciplinary approach that includes general surgeons, thoracic surgeons, and urologists. This approach might also explain the improvement in survival between 2005 and 2009 and 2010-2014, and could highlight the importance of surgery in the era of chemotherapy using paclitaxel plus carboplatin.

Furthermore, advances in chemotherapy for the recurrent and supportive care settings might help improve survival outcomes [6]. During the next decades, enormous changes in survival are expected based on the incorporation of targeted treatments for ovarian cancer. For example, the combination of bevacizumab plus paclitaxel and carboplatin provides a survival benefit in patients with advanced-stage ovarian cancer. In addition, the GOG 218 and International Collaboration on Ovarian Neoplasms trial 7 (ICON 7) studies revealed a progression-free survival benefit in the first-line setting $[13,28]$, while three randomized phase III trials revealed a survival benefit the recurrent setting [12, 14, 29]. Moreover, mature data from phase II and III trials with PARP inhibitors will be available in the next few years, and Study 19 has already revealed a remarkable survival benefit after olaparib treatment for patients with a $B R C A$ mutation and platinum-sensitive recurrence [30]. Based on 
these results, the Korean Food and Drug Administration approved bevacizumab in 2013 and olaparib in 2016. Nevertheless, targeted drugs were rarely used during the present study's period, and only a few patients would have received targeted drugs in clinical trials.

Despite the progress in treating serous carcinoma during the last 20 years, we did not observe any survival improvements for the mucinous and clear cell carcinoma subtypes. Although epithelial ovarian cancer has significant heterogeneity and the histological subtype is a well-known prognostic factor, the current management strategies do not consider the histological subtype. Previous studies have confirmed that patients with mucinous tumors have inferior long-term survival, compared to the serous or endometrioid subtypes, which is related to a poor response to platinum-based chemotherapy [31, 32]. However, advances in the pathological diagnosis of ovarian mucinous carcinoma have allowed pathologists to distinguish between primary and metastatic mucinous carcinoma, which has led pathologist to suggest that primary ovarian mucinous tumors are rare [33]. The GOG 241 study aimed to compare the efficacy of carboplatin plus paclitaxel $+/$ - bevacizumab to that of oxaliplatin plus capecitabine $+/-$ bevacizumab as first-line chemotherapy for patients with mucinous adenocarcinoma, although there has been limited enrollment in that study because of this subtype's rarity.

The incidence of clear cell carcinoma has increased markedly in Korea across all age groups since 1999 [2]. Previous reports have confirmed that women with endometriosis have an elevated risk of developing clear cell carcinoma, and this trend is expected to continue in the near future, based on the increasing incidence of endometriosis in Korea [34, 35]. The JGOG 3017 study compared the efficacy of irinotecan plus cisplatin versus paclitaxel plus carboplatin as a first-line chemotherapy [36], although no subtype-specific survival benefits were observed for the irinotecan plus cisplatin regimen. Chan et al. did not report any change in survival rates for patients with clear cell carcinoma after analyzing the data available on the Surveillance Epidemiology and End Results Database [4]. Therefore, treatment using existing anticancer agents has limited ability to improve the prognosis of patients with clear cell carcinoma. The present study also revealed poor survival outcomes and no improvement in the outcomes for advanced-stage clear carcinoma.

The present study is one of the largest population-based studies to evaluate the survival rate of ovarian cancer using available histological and cancer stage data. Although the present study's findings are strengthened by the large nationally representative sample of Korean women, there are also several limitations. First, the KCCR database does not include disease information such as
International Federation of Gynecology and Obstetrics (FIGO) staging and survival information such as recurrence and the cause of death. Hence, we could not identify the specific cause of death for each case. In addition, the sociodemographic information such as region, residence and hospital cannot be obtained from the KCCR database for research purpose. Therefore, we could not analyze the data obtained for the indicators related to the health system. Second, there is no detailed information regarding the surgery and chemotherapy, such as surgeon specialty, extent of debulking, residual disease, neoadjuvant or postoperative chemotherapy, and the specific regimens. Thus, as we observed an improved survival rate among patients who underwent surgery, it is possible that this finding was biased by the selection of healthier patients in the surgery group. Third, central pathology reviews are not performed for patients who are registered in the KCCR.

\section{Conclusion}

Ovarian cancer survival has improved in Korea during the last 20 years. However, no improvements were observed for the mucinous and clear cell carcinoma subtypes. Given the low survival rate in cases with advanced-stage mucinous/clear cell subtypes, clinical trials with novel treatment strategies are urgently needed to improve clinical outcomes in these cases.

\section{Abbreviations}

FIGO: International Federation of Gynecology and Obstetrics;

GOG: Gynecologic Oncology Group; ICD-10: International Statistical Classification of Diseases and Related Health Problems, 10th edition; KCCR: Korea Central Cancer Registry; KNCIDB: Korean National Cancer Incidence Database; RER: Relative excess risks; RSR: Relative survival rate; SEER: Surveillance, Epidemiology, and End Results

\section{Funding}

This study was supported in part by a National Cancer Center Grant (Grant No. NCC-1610200) and a new faculty research seed money grant of Yonsei University College of Medicine for 2017 (Grant No. 2017-32-0033). The funding bodies played no role in the design and conduct of the study; collection, analysis, and interpretation of data; writing of the manuscript, and the decision to submit the manuscript for publication.

\section{Availability of data and materials}

All data generated or analyzed during this study are included in this published article.

\section{Authors' contributions}

JYL and YJW were responsible for the study design. BL and YJW participated in data collection. BL analyzed the data. JYL, MCL, BL, KWJ and YJW were involved in the interpretation of the data. JYL and YJW drafted the manuscript. JYL, SK, YTK, MCL, JWK, S-YP and YJW revised the manuscript. All authors critically read the drafts of this paper and approved its final version.

\section{Ethics approval and consent to participate}

Ethical approval for the research protocol was provided by the institutional review board of the National Cancer Center (NCC2017-0168) which waived the requirement for informed consent. The authorization for data processing was obtained from the National 'Cancer Control Act'. 


\section{Competing interests}

The authors declare that they have no competing interests.

\section{Publisher's Note}

Springer Nature remains neutral with regard to jurisdictional claims in published maps and institutional affiliations.

\section{Author details}

'Department of Obstetrics and Gynecology, Institute of Women's Life Medical Science, Yonsei University College of Medicine, Seoul, South Korea. ${ }^{2}$ Gynecologic Cancer Branch \& Center for Uterine Cancer, National Cancer Center, Goyang, South Korea. ${ }^{3}$ Cancer Registration and Statistics Branch, National Cancer Center, Goyang, South Korea. ${ }^{4}$ Department of Obstetrics and Gynecology, Seoul National University College of medicine, Seoul, South Korea

\section{Received: 27 September 2017 Accepted: 9 May 2018}

Published online: 29 May 2018

\section{References}

1. Jung KW, Won YJ, Oh CM, Kong HJ, Lee DH, Lee KH. Cancer statistics in Korea: incidence, mortality, survival, and prevalence in 2014. Cancer Res Treat. 2017:49(2):292-305.

2. Kim SI, Lim MC, Lim J, Won YJ, Seo SS, Kang S, Park SY. Incidence of epithelial ovarian cancer according to histologic subtypes in Korea, 1999 to 2012. J Gynecol Oncol. 2016;27(1):e5.

3. Lee JY, Kim EY, Jung KW, Shin A, Chan KK, Aoki D, Kim JW, Low JJ, Won YJ. Trends in gynecologic cancer mortality in east Asian regions. J Gynecol Oncol. 2014;25(3):174-82

4. Chan JK, Cheung MK, Husain A, Teng NN, West D, Whittemore AS, Berek JS, Osann K. Patterns and progress in ovarian cancer over 14 years. Obstet Gynecol. 2006;108(3 Pt 1):521-8.

5. Wright JD, Chen L, Tergas Al, Patankar S, Burke WM, Hou JY, Neugut Al, Ananth CV, Hershman DL. Trends in relative survival for ovarian cancer from 1975 to 2011. Obstet Gynecol. 2015;125(6):1345-52.

6. Shimada T, Saito T, Shimokawa M, Shimamoto K, Matsushita S, Yamaguchi S, Ariyoshi K, Okadome M. Improvement in the prognosis of ovarian cancer in the era before addition of molecular targeting therapy. Jpn J Clin Oncol. 2017;47(6):494-8

7. Chang SJ, Bristow RE, Ryu HS. Impact of complete cytoreduction leaving no gross residual disease associated with radical cytoreductive surgical procedures on survival in advanced ovarian cancer. Ann Surg Oncol. 2012; 19(13):4059-67.

8. Bristow RE, Tomacruz RS, Armstrong DK, Trimble EL, Montz FJ. Survival effect of maximal cytoreductive surgery for advanced ovarian carcinoma during the platinum era: a meta-analysis. J Clin Oncol. 2002;20(5):1248-59.

9. Piccart MJ, Bertelsen K, James K, Cassidy J, Mangioni C, Simonsen E, Stuart G, Kaye $\mathrm{S}$, Vergote I, Blom R, et al. Randomized intergroup trial of cisplatin-paclitaxel versus cisplatin-cyclophosphamide in women with advanced epithelial ovarian cancer: three-year results. J Natl Cancer Inst. 2000;92(9):699-708.

10. du Bois A, Luck HJ, Meier W, Adams HP, Mobus V, Costa S, Bauknecht T, Richter B, Warm M, Schroder W, et al. A randomized clinical trial of cisplatin/ paclitaxel versus carboplatin/paclitaxel as first-line treatment of ovarian cancer. J Natl Cancer Inst. 2003:95(17):1320-9.

11. Ozols RF, Bundy BN, Greer BE, Fowler JM, Clarke-Pearson D, Burger RA, Mannel RS, DeGeest K, Hartenbach EM, Baergen R. Phase III trial of carboplatin and paclitaxel compared with cisplatin and paclitaxel in patients with optimally resected stage III ovarian cancer: a gynecologic oncology group study. J Clin Oncol. 2003;21(17):3194-200.

12. Aghajanian C, Blank SV, Goff BA, Judson PL, Teneriello MG, Husain A, Sovak MA, Yi J, Nycum LR. OCEANS: a randomized, double-blind, placebocontrolled phase III trial of chemotherapy with or without bevacizumab in patients with platinum-sensitive recurrent epithelial ovarian, primary peritoneal, or fallopian tube cancer. J Clin Oncol. 2012;30(17):2039-45

13. Burger RA, Brady MF, Bookman MA, Fleming GF, Monk BJ, Huang $H$, Mannel RS, Homesley HD, Fowler J, Greer BE, et al. Incorporation of bevacizumab in the primary treatment of ovarian cancer. $N$ Engl J Med. 2011;365(26):2473-83.

14. Pujade-Lauraine E, Hilpert F, Weber B, Reuss A, Poveda A, Kristensen G, Sorio $R$, Vergote I, Witteveen P, Bamias A, et al. Bevacizumab combined with chemotherapy for platinum-resistant recurrent ovarian cancer: the AURELIA open-label randomized phase III trial. J Clin Oncol. 2014;32(13):1302-8.

15. Cohn DE, Barnett JC, Wenzel L, Monk BJ, Burger RA, Straughn JM Jr, Myers $E R$, Havrilesky $\amalg$. A cost-utility analysis of NRG oncology/gynecologic oncology group protocol 218: incorporating prospectively collected qualityof-life scores in an economic model of treatment of ovarian cancer. Gynecol Oncol. 2015;136(2):293-9.

16. Lee JY, Kim K, Lee YS, Kim HY, Nam EJ, Kim S, Kim SW, Kim JW, Kim YT. Treatment preferences of advanced ovarian cancer patients for adding bevacizumab to first-line therapy. Gynecol Oncol. 2016;143(3):622-7.

17. Fritz A, Percy C, Jack A, Shanmugaratnam K, Sobin L, Parkin DM, Whelan S. International classification of diseases for oncology. 3rd ed. Geneva, Switzerland: World Health Organization; 2000.

18. World Health Organization. International statistical classification of diseases and related health problems, 10th rev. Geneva: World Health Organization; 1994

19. Young JL Jr, Roffers SD, Ries LAG, Fritz AG, Hurlbut AA. SEER summary staging Manual-2000: codes and coding instructions. Bethdsda: National Cancer Institute, $\mathrm{NIH} ; 2001$.

20. Ederer $\mathrm{F}$, Heise $\mathrm{H}$. Instructions to IBM 650 programmers in processing survival computations. In: Methodological note no10. Bethesda: National Cancer Institute; 1959

21. Cox DR. Regression models and life-tables (with discussion). J R Stat Soc. 1972;34(2):187-220.

22. Kelin JP, Moeschberger ML. Survival analysis: techniques for censored and truncated data. New York: Springer-Verlag; 1997.

23. Bristow RE, Chang J, Ziogas A, Campos B, Chavez LR, Anton-Culver H. Impact of National Cancer Institute Comprehensive Cancer centers on ovarian cancer treatment and survival. J Am Coll Surg. 2015;220(5):940-50.

24. Lee JY, Kim TH, Suh DH, Kim JW, Kim HS, Chung HH, Park NH, Song YS, Kang SB. Impact of guideline adherence on patient outcomes in early-stage epithelial ovarian cancer. Eur J Surg Oncol. 2015;41(4):585-91.

25. McGuire WP, Hoskins WJ, Brady MF, Kucera PR, Partridge EE, Look KY, ClarkePearson DL, Davidson M. Cyclophosphamide and cisplatin compared with paclitaxel and cisplatin in patients with stage III and stage IV ovarian cancer. N Engl J Med. 1996:334(1):1-6.

26. Armstrong DK, Bundy B, Wenzel L, Huang HQ, Baergen R, Lele S, Copeland $\amalg$, Walker JL, Burger RA. Intraperitoneal cisplatin and paclitaxel in ovarian cancer. N Engl J Med. 2006;354(1):34-43.

27. Katsumata N, Yasuda M, Takahashi F, Isonishi S, Jobo T, Aoki D, Tsuda H, Sugiyama T, Kodama S, Kimura E, et al. Dose-dense paclitaxel once a week in combination with carboplatin every 3 weeks for advanced ovarian cancer: a phase 3, open-label, randomised controlled trial. Lancet. 2009; 374(9698):1331-8.

28. Perren TJ, Swart AM, Pfisterer J, Ledermann JA, Pujade-Lauraine E, Kristensen G, Carey MS, Beale P, Cervantes A, Kurzeder C, et al. A phase 3 trial of bevacizumab in ovarian cancer. N Engl J Med. 2011;365(26):2484-96.

29. Coleman RL, Brady MF, Herzog TJ, Sabbatini P, Armstrong DK, Walker JL, Kim BG, Fujiwara K, Tewari KS, O'Malley DM, et al. Bevacizumab and paclitaxel-carboplatin chemotherapy and secondary cytoreduction in recurrent, platinum-sensitive ovarian cancer (NRG oncology/gynecologic oncology group study GOG-0213): a multicentre, open-label, randomised, phase 3 trial. Lancet Oncol. 2017;18(6):779-91.

30. Ledermann J, Harter P, Gourley C, Friedlander M, Vergote I, Rustin G, Scott $\mathrm{CL}$, Meier W, Shapira-Frommer R, Safra T, et al. Olaparib maintenance therapy in patients with platinum-sensitive relapsed serous ovarian cancer: a preplanned retrospective analysis of outcomes by BRCA status in a randomised phase 2 trial. Lancet Oncol. 2014;15(8):852-61.

31. Hess V, A'Hern R, Nasiri N, King DM, Blake PR, Barton DP, Shepherd JH, Ind T, Bridges J, Harrington K, et al. Mucinous epithelial ovarian cancer: a separate entity requiring specific treatment. J Clin Oncol. 2004;22(6):1040-4.

32. Winter WE 3rd, Maxwell GL, Tian C, Carlson JW, Ozols RF, Rose PG, Markman M, Armstrong DK, Muggia F, McGuire WP. Prognostic factors for stage III epithelial ovarian cancer: a gynecologic oncology group study. J Clin Oncol. 2007;25(24):3621-7.

33. Seidman JD, Kurman R, Ronnett BM. Primary and metastatic mucinous adenocarcinomas in the ovaries: incidence in routine practice with a new approach to improve intraoperative diagnosis. Am J Surg Pathol. 2003;27(7):985-93.

34. Kim HS, Kim TH, Chung HH, Song YS. Risk and prognosis of ovarian cancer in women with endometriosis: a meta-analysis. Br J Cancer. 2014;110(7):1878-90. 
35. Lim MC, Lee DO, Kang S, Seo SS, Lee BY, Park SY. Clinical manifestations in patients with ovarian clear cell carcinoma with or without co-existing endometriosis. Gynecol Endocrinol. 2009;25(7):435-40.

36. Sugiyama T, Okamoto A, Enomoto T, Hamano T, Aotani E, Terao Y, Suzuki N, Mikami M, Yaegashi N, Kato K, et al. Randomized phase III trial of irinotecan plus cisplatin compared with paclitaxel plus carboplatin as first-line chemotherapy for ovarian clear cell carcinoma: JGOG3017/GCIG trial. J Clin Oncol. 2016:34(24):2881-7.

Ready to submit your research? Choose BMC and benefit from:

- fast, convenient online submission

- thorough peer review by experienced researchers in your field

- rapid publication on acceptance

- support for research data, including large and complex data types

- gold Open Access which fosters wider collaboration and increased citations

- maximum visibility for your research: over $100 \mathrm{M}$ website views per year 